\title{
Synaptic Activation of Presynaptic Glutamate Transporter Currents in Nerve Terminals
}

\author{
Mary J. Palmer, Holger Taschenberger, Court Hull, Liisa Tremere, and Henrique von Gersdorff \\ The Vollum Institute, Oregon Health and Science University, Portland, Oregon 97239
}

\begin{abstract}
Glutamate uptake by high-affinity transporters is responsible for limiting the activation of postsynaptic receptors and maintaining low levels of ambient glutamate. The reuptake process generates membrane currents, which can be activated by synaptically released glutamate in glial cells and some postsynaptic neurons. However, less is known about presynaptic transporter currents because the small size of synaptic boutons precludes direct recordings. Here, we have recorded from two giant nerve terminals: bipolar cell synaptic terminals in goldfish retina and the calyx of Held in rat auditory brainstem. Exocytosis was evoked by brief depolarizations and measured as an increase in membrane capacitance. In isolated bipolar cell terminals, exocytosis was associated with an anion $\left(\mathrm{NO}_{3}{ }^{-}\right.$or Cl$\left.{ }^{-}\right)$current. The current peaked $2.8 \mathrm{msec}$ after the start of the depolarization and decayed with a mean time constant of $8.5 \mathrm{msec}$. It was inhibited by the nontransportable glutamate transporter antagonist DL-threo- $\beta$-benzyloxyaspartate (TBOA) but was insensitive to the GLT1/EAAT2 subtype-selective antagonist dihydrokainate and was affected by extracellular $\mathrm{pH}$ buffering. A TBOA-sensitive anion current was also evoked by application of exogenous glutamate to bipolar cell terminals. The large single-channel conductance, derived from noise analysis, and previous immunolocalization studies suggest that synaptically released glutamate activates EAAT5-type transporters in bipolar cell terminals. In contrast, neither exocytosis nor exogenous glutamate evoked a transporter current in the calyx of Held. Glutamate transporter currents with rapid kinetics are therefore identified and characterized in bipolar cell terminals, providing a valuable system for investigating the function and modulation of presynaptic glutamate transporters.
\end{abstract}

Key words: glutamate transporters; uptake; presynaptic terminal; exocytosis; retinal bipolar cell; synaptic ribbons; calyx of Held; auditory brainstem; EAAT5 anion current

\section{Introduction}

Glutamate reuptake is mediated by high-affinity transporters that are present in neuronal and glial membranes (for review, see Danbolt, 2001). To date, five glutamate transporter subtypes have been identified, called EAAT (excitatory amino acid transporter) 1-5. Expression in oocytes has enabled detailed study of their properties and provided evidence that glutamate transport is driven by the coupled cotransport of three $\mathrm{Na}^{+}$and one $\mathrm{H}^{+}$ and the countertransport of one $\mathrm{K}^{+}$(Zerangue and Kavanaugh, 1996; Levy et al., 1998). As a result, glutamate uptake produces net inward current. In addition, binding of glutamate to transporters activates an uncoupled anion conductance, which is particularly prominent in EAAT4 and EAAT5, with intracellular chaotropic anions (Fairman et al., 1995; Wadiche et al., 1995; Billups et al., 1996; Arriza et al., 1997). Thus, it is possible to detect glutamate transporter activation by recording membrane currents.

\footnotetext{
Received Sept. 6, 2002; revised Feb. 24, 2003; accepted Feb. 24, 2003.

This work was supported by National Institutes of Health and Pew Biomedical Research Scholar grants. We thank Drs. G. Awatramani (Oregon Health Sciences University) and M. Freed (University of Pennsylvania) for advice on retinal slice preparation; Drs. M. Kavanaugh, P. Larsson, K. Matsui, A. Tzingounis, and J. Wadiche for valuable discussions; and Dr. C. E. Jahr for computer simulations of glutamate transporter currents.

Correspondence should be addressed to Dr. H. von Gersdorff, The Vollum Institute, Oregon Health Sciences University, 3181 Southwest Sam Jackson Park Road, Portland, OR 97239. E-mail: vongersd@ohsu.edu.

M. J. Palmer's present address: Medical Research Council Centre for Synaptic Plasticity, University of Bristol, BS81TD UK.

H. Taschenberger's present address: Department of Membrane Biophysics, Max Planck Institute for Biophysical Chemistry, Göttingen, D-37077 Germany.

Copyright $\odot 2003$ Society for Neuroscience $\quad$ 0270-6474/03/234831-11\$15.00/0
}

The expression of glutamate transporters in glial cells and postsynaptic neurons is well established, and their activation by synaptically released glutamate has been studied in CA1 astrocytes (Bergles and Jahr, 1997), Bergmann glia (Bergles et al., 1997; Clark and Barbour, 1997), Purkinje cells (Otis et al., 1997; Auger and Attwell, 2000), and retinal bipolar cell dendrites (Grant and Dowling, 1996). In addition, there is evidence for glutamate transporters in the presynaptic terminals of certain neurons. For example, D-aspartate uptake by glutamate transporters has been detected in synaptic terminals of the hippocampus (Gundersen et al., 1993), in which the glutamate transporter subtype EAAC1 (homolog of EAAT3) has been immunolocalized to presynaptic structures (He et al., 2000). In photoreceptors, presynaptic transporter currents have been recorded in response to exogenous glutamate (Sarantis et al., 1988; Tachibana and Kaneko, 1988; Eliasof and Werblin, 1993) and spontaneous quantal glutamate release (Picaud et al., 1995a). The transporter subtypes GLT1 and EAAT5 have been immunolocalized to both photoreceptors and the synaptic terminals of retinal bipolar cells (Rauen et al., 1996; Pow and Barnett, 2000; Vandenbranden et al., 2000; Reye et al., 2002). However, because of the inaccessibility of most presynaptic terminals to electrophysiological recording, the functional properties of presynaptic transporter currents activated by synaptically released glutamate remain poorly understood.

We took advantage of the exceptionally large glutamatergic nerve terminals of bipolar cells in the goldfish retina (Tachibana and Okada, 1991; Heidelberger and Matthews, 1992) and the 
calyx of Held synapse in rat brainstem (Forsythe and BarnesDavies, 1993) to identify presynaptic glutamate transporters. We first show that time-resolved membrane capacitance measurements are feasible from isolated bipolar cell terminals embedded within retinal slices. We report that glutamate release from bipolar cell terminals but not from the calyx of Held is followed by the activation of a glutamate transporter-associated anion current. We characterize the kinetic properties, ion selectivity, and pharmacology of this newly identified current and estimate the underlying single-channel conductance using noise analysis (Larsson et al., 1996). Finally, we discuss the possible roles for these presynaptic glutamate transporters in transmitter reuptake and retinal signaling.

\section{Materials and Methods}

Retinal slice preparation. Retinal slices were prepared from goldfish (Carassius auratus; $8-14 \mathrm{~cm}$ ) after $1 \mathrm{hr}$ dark adaptation. In brief, isolated retina was treated for $15 \mathrm{~min}$ with hyaluronidase to remove vitreous humor, cut into four or five pieces, placed ganglion cell layer down on filter paper, and sliced at $250 \mu \mathrm{m}$ intervals using a Narishige slicer (ST20; Tokyo, Japan). Slices were transferred to the recording chamber and perfused continuously $(1 \mathrm{ml} / \mathrm{min}$ ) with medium comprising (mM): 120 $\mathrm{NaCl}, 2.5 \mathrm{KCl}, 1.0 \mathrm{MgCl}_{2}, 2.5 \mathrm{CaCl}_{2}, 12 \mathrm{HEPES}$, and 12 glucose, at a $\mathrm{pH}$ of 7.45 (set with $\mathrm{NaOH}$ ) and $260 \mathrm{mOsm}$. For experiments requiring a higher ( $48 \mathrm{~mm}$ ) or lower ( $3 \mathrm{~mm}$ ) HEPES concentration, the amounts of $\mathrm{NaCl}$ and $\mathrm{NaOH}$ were adjusted to maintain osmolarity and $\mathrm{pH}$. Slice preparation and recordings were performed at room temperature (21$23^{\circ} \mathrm{C}$ ) in daylight conditions.

Identification of bipolar cell terminals. Slices were viewed with differential interference contrast (DIC) optics through a $40 \times$ water-immersion objective and 1.6× zoom (Axioskop; Zeiss, Oberkochen, Germany) and a CCD camera (Hamamatsu, Tokyo, Japan). Bipolar cell terminals were identified by their size, shape, and position in the slice (see Fig. 1a) and depolarization-evoked $\mathrm{Ca}^{2+}$ currents and capacitance responses. A subset of terminals were isolated because of severing of the bipolar cell axon during the slicing procedure; this was determined from the capacitive current response to a $-10 \mathrm{mV}$ step (see Fig. $1 c, d$ ). Terminals fell clearly into two groups: one group was well fit with a double-exponential function with a prominent slow component $\left(\tau_{\mathrm{s}}=1.5 \pm 0.1 \mathrm{msec}\right)$ and had low input resistance $(<0.5 \mathrm{G} \Omega)$; the other group was well fit by either a single fast exponential $\left(\tau_{\mathrm{f}}=98 \pm 5 \mu \mathrm{sec}\right)$ or a double exponential with only a minor slow component and had high input resistance $(>1 \mathrm{G} \Omega$ ). The first group was classified as intact cells and the second as isolated terminals (Mennerick et al., 1997). This classification was confirmed using Lucifer yellow to image recorded terminals (see Fig. 1b). Intact cells and isolated terminals had baseline membrane capacitance measurements of 9-15 and 3-7 pF, respectively. To avoid potential complications from glutamate transporters or ion channels in the soma and dendrites and to minimize voltage-clamp error, only isolated terminals were used for this study.

Bipolar cell terminal recordings. Whole-cell voltage-clamp recordings were obtained using 5-8 $\mathrm{M} \Omega$ patch pipettes pulled from thick-walled borosilicate glass (World Precision Instruments, Sarasota, FL) using a Narishige puller (PP-830; Tokyo, Japan). Pipettes were coated with dental wax to reduce their capacitance and filled with solution comprising (mM): $115 \mathrm{CsNO}_{3}, 25$ HEPES, 10 TEA-Cl, $3 \mathrm{Mg}$-ATP, $0.5 \mathrm{Na}-\mathrm{GTP}$, and 0.5 EGTA, at a pH of 7.2 and $270 \mathrm{mOsm}$. $\mathrm{CsNO}_{3}$ was replaced with $\mathrm{Cs}$ gluconate, $\mathrm{CsCl}$, or $\mathrm{KCl}$ where stated. Series resistance was typically $10-15 \mathrm{M} \Omega$ and leak current $<50 \mathrm{pA}$ at a holding potential $\left(V_{\mathrm{h}}\right)$ of -60 $\mathrm{mV}$. Data acquisition was controlled by Pulse software (Heka, Lambrecht, Germany), and signals were recorded via a double EPC-9 (Heka) patch-clamp amplifier. Sampling rates and filter settings were 10 and 3 $\mathrm{kHz}$, respectively. Capacitance measurements were performed by the "sine + DC" method (Gillis, 1995). In brief, a $1 \mathrm{kHz}$ sinusoidal voltage command ( $30 \mathrm{mV}$ peak-to-peak) was added to the $V_{\mathrm{h}}$ of $-60 \mathrm{mV}$, and the resulting current was analyzed at two orthogonal phase angles by the EPC-9 software emulation of a lock-in amplifier. These signals, together with the DC current, were used to generate values for membrane capacitance, membrane conductance, and series conductance (Gillis, 1995). Off-line analysis was performed with IgorPro software (Wavemetrics, Lake Oswego, OR).

Drug application. Drugs were bath-applied in the perfusing medium. For experiments requiring brief application of glutamate, a Picospritzer was used to apply pressure ( 9 psi for $500 \mathrm{msec}$ ) to the back of a patch pipette $(\sim 5 \mathrm{M} \Omega$ ) positioned above the slice within $20 \mu \mathrm{m}$ of the terminal. The pipette contained standard extracellular solution plus bath-applied antagonists and 10 mM L-glutamate. Picrotoxin, strychnine, and THA (DL-threo-3hydroxyaspartate) were obtained from Sigma (St Louis, MO); NBQX (2,3dioxo-6-nitro-1,2,3,4-tetrahydrobenzo[f] quinoxaline-7-sulfonamide), DL-AP-5 (DL-2-amino-5-phosphonopentanoic acid), TBOA (DL-threo- $\beta$ benzyloxyaspartate), DHK (dihydrokainate), MCPG [( $S)$ - $\alpha$-methyl-4carboxyphenylglycine], and CPPG [(RS)- $\alpha$-cyclopropyl-4-phosphonophenylglycine] were obtained from Tocris (Bristol, UK). All other chemicals and salts were obtained from Sigma.

Noise analysis. Nonstationary noise analysis of transporter currents was performed as described previously for synaptic currents (Traynelis et al., 1993; Benke et al., 1998). Sequential currents (10-20) were baselinesubtracted and averaged, and the mean current waveform was peakscaled to each response. Variance $\left(\sigma^{2}\right)$ was measured from the peak to the end of the current decay, averaged for all responses, and plotted against mean current amplitude $(I)$. The data were fit by the following equation: $\sigma^{2}=i I-I^{2} / N+b_{1}$, yielding estimates of single-channel current $(i)$, the average number of channels open at the peak of the current $(N)$, and baseline variance $\left(b_{1}\right)$. Recordings were not used if there was a change in either the latency of the peak or the rate of decay of responses. Peak scaling was necessary because response amplitude gradually decreased during recordings because of rundown of transmitter release from the terminal (see Results). When responses were analyzed separately from early and late stages of a recording, there was a decrease in $N$ but no change in single-channel current $(i)$ associated with the decrease in mean current amplitude. For noise analysis of glutamate-activated currents, a plot of variance versus mean amplitude was obtained for the decay of each response and fit with the following equation: $\sigma^{2}=i I-I^{2} / N+b_{1}$ to obtain an estimate of $i$. Data are expressed as mean \pm SEM. Statistical difference was assessed using two-tailed Student's $t$ test, with a value of $p<0.05$ considered significant.

Brainstem slice preparation. Brainstem slices were obtained from postnatal day 5 (P5) to P14 Sprague Dawley rats. After decapitation, the brainstem was immersed in ice-cold low- $\mathrm{Ca}^{2+}$ artificial CSF (aCSF) containing (mM): $125 \mathrm{NaCl}, 2.5 \mathrm{KCl}, 3.0 \mathrm{MgCl}_{2}, 0.1 \mathrm{CaCl}_{2}, 25$ glucose, 25 $\mathrm{NaHCO}_{3}, 1.25 \mathrm{NaH}_{2} \mathrm{PO}_{4}, 0.4$ ascorbic acid, 3 myoinositol, and $2 \mathrm{Na}-$ pyruvate, at a $\mathrm{pH}$ of 7.3 when bubbled with carbogen $\left(95 \% \mathrm{O}_{2} / 5 \% \mathrm{CO}_{2}\right)$. Slices $200 \mu \mathrm{m}$ thick were cut, proceeding from a caudal to rostral direction. Slices were transferred to an incubation chamber containing normal aCSF bubbled with carbogen and maintained at $35^{\circ} \mathrm{C}$ for $30 \mathrm{~min}$ and thereafter at room temperature. Normal aCSF was the same as low-Ca ${ }^{2+}$ aCSF except that $1.0 \mathrm{~mm} \mathrm{MgCl}_{2}$ and $2.0 \mathrm{~mm} \mathrm{CaCl}_{2}$ were used.

Calyx of Held recordings. Whole-cell voltage-clamp recordings were performed in normal aCSF at room temperature $\left(21-23^{\circ} \mathrm{C}\right)$. All intracellular solutions contained $\mathrm{NO}_{3}{ }^{-}$as the major anion to augment glutamate transporter associated currents. To record currents evoked by application of exogenous glutamate, the patch pipette was filled with solution composed of (mM): $130 \mathrm{KNO}_{3}, 20 \mathrm{KCl}, 5 \mathrm{Na}_{2}$-phosphocreatine, 10 HEPES, 0.2 EGTA, and 4 ATP-Mg, at a pH adjusted to 7.3 with $\mathrm{KOH}$. Electrophoretic pipettes $(20-50 \mathrm{M} \Omega)$ were filled with L-glutamate $(0.5 \mathrm{M}$, $\mathrm{pH}$ 7.5) and placed within $20 \mu \mathrm{m}$ of the presynaptic terminal. Iontophoretic pulses were applied once every $3 \mathrm{~min}$. The pipette solution for recording presynaptic $\mathrm{Ca}^{2+}$ currents and membrane capacitance changes was composed of (mM): $130 \mathrm{CsNO}_{3}, 15 \mathrm{CsCl}, 20$ TEA-Cl, 5 $\mathrm{Na}_{2}$-phosphocreatine, 10 HEPES, 0.2 EGTA, and 4 ATP-Mg, at a $\mathrm{pH}$ 
adjusted to 7.3 with $\mathrm{CsOH}$. TTX $(0.5 \mu \mathrm{M})$ and TEA ( $5 \mathrm{~mm}$ ) were added to the bath to block voltage-activated sodium and potassium currents. During experiments, slices were perfused continuously with normal aCSF and visualized by infrared-DIC microscopy through a $40 \times$ water-immersion objective (Axioskop; Zeiss, Germany) coupled to $2 \times$ premagnification (Optovart; Zeiss) and a CCD camera (C79; Hamamatsu). Calyces were identified visually for whole-cell recording. The capacitive current transient of the calyces could be fit by a monoexponential or a double-exponential function, indicating short and long axon stumps, respectively. However, the average capacitance jump elicited by step depolarizations was similar for calyces requiring monoexponential and double-exponential fits (Taschenberger et al., 2002). Patch pipettes were pulled from soft thin-walled glass (World Precision Instruments, Sarasota, FL) and had an open-tip resistance of 3-5 $\mathrm{M} \Omega$. Series resistance $\left(\mathrm{R}_{\mathrm{S}}\right)$ was $<20 \mathrm{M} \Omega$, and $\mathrm{R}_{\mathrm{S}}$ compensation was set to $\sim 60 \%$. Stimulation pulses were controlled using Pulse software (Heka), and signals were recorded via a double EPC-9 (Heka) patchclamp amplifier. Sampling rates and filter settings were 50 and $4 \mathrm{kHz}$, respectively. Membrane capacitance measurements were performed as for the bipolar cell terminals, except that $V_{\mathrm{h}}$ was $-80 \mathrm{mV}$ and the sine-wave peak-to-peak amplitude was $60 \mathrm{mV}$. For offline analysis, IgorPro software was used (Wavemetrics).

\section{Results \\ Exocytosis is followed by an inward current in bipolar cell terminals}

Whole-cell patch-clamp recordings were made from visually identified bipolar cell terminals in slices of goldfish retina (Fig. $1 a, b)$. Because glutamate transporter currents have been identified in the dendrites of teleost bipolar cells (Grant and Dowling, 1995), somatic and dendritic currents were eliminated by recording only from terminals that had been isolated by severing of the axon during the slicing procedure. Isolated terminals also have the advantage of a simple electrotonic structure (spherical) (Mennerick et al., 1997), which reduces artifacts in time-resolved membrane capacitance measurements and enables fast voltageclamping (Gillis, 1995). Isolated terminals were identified from the current response to a $-10 \mathrm{mV}$ step (Fig. 1c,d) (see Materials and Methods). Previously, isolated bipolar cell terminals dissociated acutely from goldfish retina have been used to study neurotransmitter release by measurement of depolarization-evoked changes in membrane capacitance (von Gersdorff and Matthews, 1994). They exhibit pronounced paired-pulse depression of exocytosis (Mennerick and Matthews, 1996; Burrone and Lagnado, 2000) and glutamate release (von Gersdorff et al., 1998), which is not a result of a depression of $\mathrm{Ca}^{2+}$ influx. We therefore used differences in the membrane currents evoked by the first and second stimuli of a paired-pulse protocol to identify currents associated with glutamate release from bipolar cell terminals.

Experiments were performed with $\mathrm{NO}_{3}{ }^{-}$as the major intracellular anion to augment currents through transporter- b

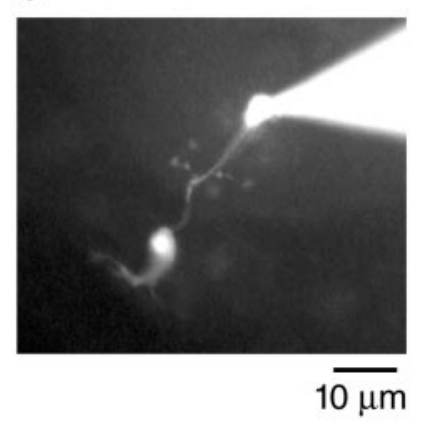

d Isolated terminal
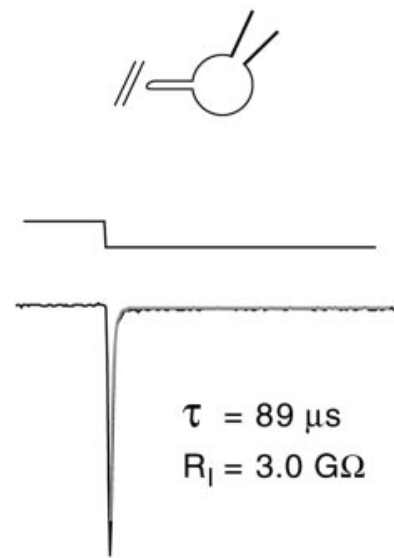

Figure 1. Identification of isolated bipolar cell terminals in retinal slices. $a$, DIC image of the inner nuclear and inner plexiform capacitive current decay and a relatively large steady-state current during the voltage step because of low input resistance $\left(R_{1}\right)$. Baseline membrane capacitance for this cell was $12.5 \mathrm{pF}$. $d$, An isolated bipolar cell terminal has a fast monoexponential current decay and high input resistance. This terminal had baseline membrane capacitance of $4.2 \mathrm{pF}$. Only isolated synaptic terminals were used for subsequent recordings.

associated anion channels (Wadiche et al., 1995). The extracellular solution contained picrotoxin $(50 \mu \mathrm{M})$ and strychnine $(1 \mu \mathrm{M})$ to block inhibitory currents evoked by GABA and glycine released from amacrine cells. From a holding potential $\left(V_{\mathrm{h}}\right)$ of -60 $\mathrm{mV}$, two $1 \mathrm{msec}$ depolarizations to $0 \mathrm{mV}$ were delivered with an interpulse interval of $100 \mathrm{msec}$. The first depolarization evoked a $\mathrm{Ca}^{2+}$ current $\left(I_{\mathrm{Ca}}\right)$ with mean peak amplitude of $-195 \pm 30 \mathrm{pA}$ $(n=10)$ (Fig. $\left.2 a_{1}\right)$ and an increase in membrane capacitance $\left(\Delta C_{\mathrm{m}}\right)$ of $15 \pm 3 \mathrm{fF}$ (Fig. $\left.2 a_{2}\right)$. This corresponds to the fusion of $\sim 600$ vesicles over 55 ribbon-type active zones, or $\sim 11$ vesicles per active zone (von Gersdorff et al., 1996). The mean amplitude of $I_{\mathrm{Ca}}$ evoked by the second depolarization was similar to that evoked by the first pulse ( $103 \pm 1 \%$, Fig. $\left.2 a_{1}\right)$, but the second pulse $\Delta C_{\mathrm{m}}$ was only $9 \pm 3 \%$ of the first pulse $\Delta C_{\mathrm{m}}$ (Fig. $2 a_{2}$ ). After repolarization to $V_{\mathrm{h}}, I_{\mathrm{Ca}}$ deactivated almost immediately (the tail current decays with a time constant of $90 \mu \mathrm{sec}$ at $-60 \mathrm{mV}$ ) (Mennerick and Matthews, 1998). However, a large inward current $\left(I_{\text {trans }}\right)$ was observed after the first depolarization (Fig. $\left.2 a_{3}\right) . I_{\text {trans }}$ peaked $2.8 \pm 0.2 \mathrm{msec}$ after the onset of the depolarizing pulse, had an average peak amplitude of $-54.9 \pm 7.3 \mathrm{pA}$, and decayed monoexponentially with a mean time constant of $8.5 \pm 0.6 \mathrm{msec}$ 


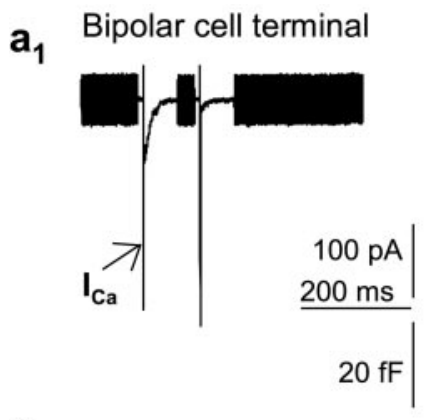

$a_{2}$
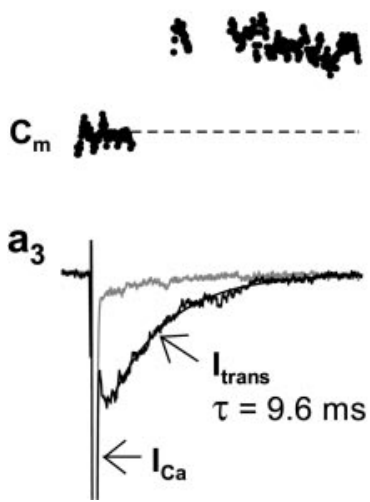

$b_{1}$

Calyx of Held

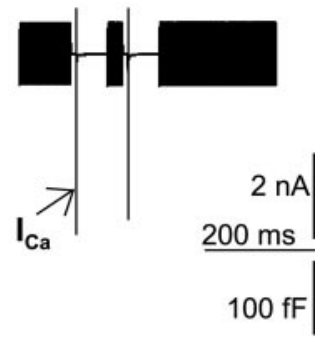

$b_{2}$

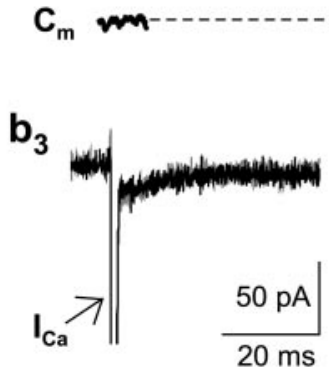

Figure 2. Depolarization-evoked exocytosis is associated with activation of $I_{\text {trans }}$ in bipolar cell terminals but not in the calyx of Held. $a$, Bipolar cell terminal response to a pair of $1 \mathrm{msec}$ depolarizations from -60 to $0 \mathrm{mV}$ with $\mathrm{CsNO}_{3}$ intracellular solution. $a_{1}$, Membrane current evoked by a $1 \mathrm{kHz}$ voltage sine wave (used to measure membrane capacitance), with depolarization-evoked $I_{\mathrm{Ca}}$ during intervals. $a_{2}$, Membrane capacitance $\left(C_{\mathrm{m}}\right)$, showing an increase after the first depolarization but no additional increase after the second depolarization. Baseline $C_{\mathrm{m}}$ for this terminal was $4.3 \mathrm{pF} . a_{3}$, Currents evoked by the first and second depolarizations superimposed on an expanded time scale (first, black; second, gray). Note $I_{\text {trans }}$ after the first but not the second depolarization. $I_{\text {trans }}$ decayed with a time constant of $9.6 \mathrm{msec} . b, \mathrm{P} 9 \mathrm{rat}$ calyx of Held response to a pair of $1 \mathrm{msec}$ depolarizations from -80 to $0 \mathrm{mV}$ with $\mathrm{CsNO}_{3}$ intracellular solution. $I_{\mathrm{Ca}}$ and $\Delta C_{\mathrm{m}}$ were much larger than for bipolar cell terminals, but $I_{\text {trans }}$ was not observed. Baseline $C_{\mathrm{m}}$ for this calyx was $21.2 \mathrm{pF}$.

$(n=10)$. After the second depolarization, the maximum amplitude of $I_{\text {trans }}$ was $19 \pm 1 \%$ of that measured after the first pulse (Fig. $2 a_{3}$ ). Addition of ionotropic glutamate receptor antagonists $\left(10 \mu \mathrm{M}\right.$ NBQX, $100 \mu \mathrm{M}$ DL-AP-5) did not inhibit $I_{\text {trans }}(n=12$, data not shown).

Changes in membrane capacitance were also used to measure depolarization-evoked release at the large terminals of the calyx of Held (Sun and $\mathrm{Wu}, 2001$ ). Whole-cell recordings were made from visually identified calyces in slices of brainstem from P5 to $\mathrm{P} 14$ rats. With $\mathrm{CsNO}_{3}$ intracellular solution, two $1 \mathrm{msec}$ depolarizations ( $100 \mathrm{msec}$ interval) from -80 to $0 \mathrm{mV}$ were delivered. $I_{\mathrm{Ca}}$ evoked by the first depolarization had a mean amplitude of $-1.4 \pm 0.1 \mathrm{nA}$, and $\Delta C_{\mathrm{m}}$ was $78 \pm 18 \mathrm{fF}(n=6)$, corresponding to the release of 600-900 synaptic vesicles (Taschenberger et al., 2002) from $\sim 600$ conventional active zones (Sätzler et al., 2002). $I_{\mathrm{Ca}}$ evoked by the second depolarization was $92 \pm 3 \%$ of the first pulse $I_{\mathrm{Ca}}$, whereas second pulse $\Delta C_{\mathrm{m}}$ was only $23 \pm 9 \%$ of the first pulse $\Delta C_{\mathrm{m}}$ (Fig. $2 b_{1}, b_{2}$ ). In contrast to bipolar cell terminals, there was no difference in the tail currents measured after the first and second depolarizations $\left(n=6\right.$, Fig. $\left.2 b_{3}\right)$.

During the course of whole-cell recordings from bipolar cell terminals, the amount of release per stimulus gradually runs down. If $I_{\text {trans }}$ is activated by released transmitter, as suggested by the correlation between $I_{\text {trans }}$ and $\Delta C_{\mathrm{m}}$ with paired pulses, a sim-
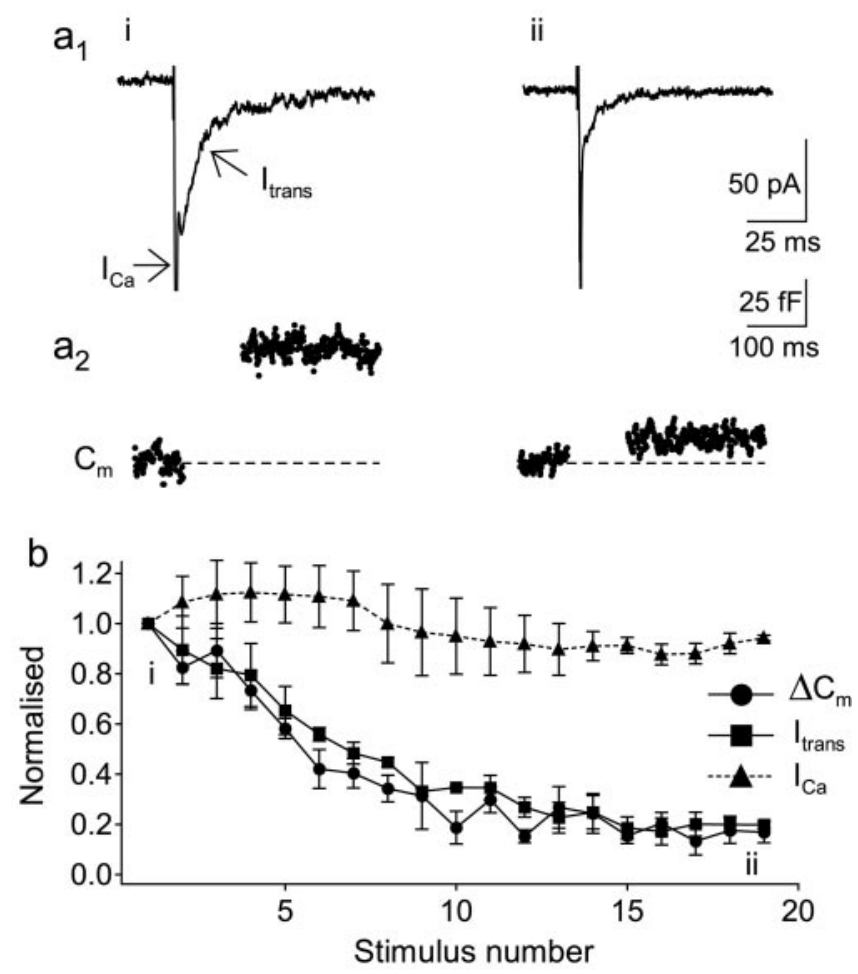

Figure 3. Correlated run-down of $\Delta C_{m}$ and $I_{\text {trans }}$ amplitude in bipolar cell terminals. $a_{1}$, Currents and $a_{2}, \Delta c_{\mathrm{m}}$ evoked by $1 \mathrm{msec}$ depolarizations from early (i) and late (ii) stages of a recording. $I_{\text {trans }}$ and $\Delta C_{m}$ decreased during the recording. Baseline $C_{m}$ for this terminal was 3.9 pF. $b, I_{\text {trans }}$ peak amplitude (measured $1.5-2.5 \mathrm{msec}$ after depolarization), $I_{\mathrm{Ca}}$ amplitude, and $\Delta C_{m}$ normalized to the first response and plotted against stimulus number. Stimulus interval was $15 \mathrm{sec}$. Mean \pm SEM for three terminals.

ilar decrease in $I_{\text {trans }}$ amplitude would be expected. Delivery of 1 msec depolarizations at $15 \mathrm{sec}$ intervals for $5 \mathrm{~min}$ was associated with a gradual decline in $\Delta C_{\mathrm{m}}$ to $17 \pm 4 \%$ of the initial value ( $n=$ 3) (Fig. $3 a_{2}, b$ ), whereas $I_{\mathrm{Ca}}$ was fairly constant during this period $(94 \pm 2 \%)$ (Fig. $3 b$ ). However, the peak amplitude of $I_{\text {trans }}$ was found to decrease to the same extent as $\Delta C_{\mathrm{m}}(20 \pm 3 \%)$, with a very similar time course $(n=3)$ (Fig. $\left.3 a_{1}, b\right) . I_{\text {trans }}$ is therefore likely to be activated by released glutamate. The rate of decay of $I_{\text {trans }}$ was independent of its amplitude, being $8.1 \pm 0.6 \mathrm{msec}$ for the first three stimuli and $7.7 \pm 0.3 \mathrm{msec}$ for the 13 th to 15 th stimuli, when the peak amplitude of $I_{\text {trans }}$ had decreased to $22 \pm$ $6 \%$ of its initial value $(n=3)$. However, the time to peak became shorter as the amplitude of $I_{\text {trans }}$ decreased such that the current appeared to peak before the end of $I_{\mathrm{Ca}}$ (Fig. $3 a_{1}$ ).

\section{Exogenous glutamate activates an inward current in bipolar cell terminals}

The expression of a glutamate-activated current in bipolar cell terminals was investigated further by puff-application of L-glutamate $(10 \mathrm{~mm})$ to isolated terminals in the presence of a mixture of bath and puff-applied ionotropic glutamate, GABA, and glycine receptor antagonists $(10 \mu \mathrm{M}$ NBQX, $100 \mu \mathrm{M}$ DL-AP-5, $50 \mu \mathrm{M}$ picrotoxin, $1 \mu \mathrm{M}$ strychnine) plus $1 \mathrm{mM} \mathrm{CdCl}_{2}$ to block $\mathrm{Ca}^{2+}$-dependent synaptic transmission. In four experiments, the metabotropic glutamate receptor (mGluR) antagonists MCPG ( $500 \mu \mathrm{M}$; blocker of group I and II mGluRs) and CPPG (200 $\mu \mathrm{M}$; blocker of group II and III mGluRs) were also included in the extracellular solution. In the presence of these antagonists and with $\mathrm{CsNO}_{3}$ intracellular solution, L-glutamate evoked a large, slowly decaying inward current $\left(I_{\text {glu }}\right)$ with a mean peak amplitude 


\section{Bipolar cell terminal}

a Control

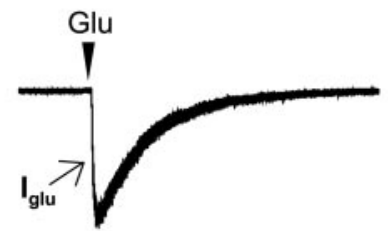

b
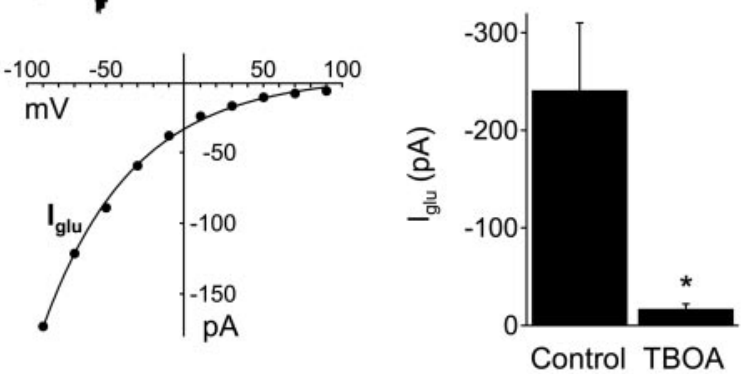

c TBOA

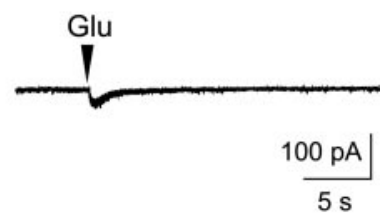

Control TBOA

\section{Calyx of Held}

d

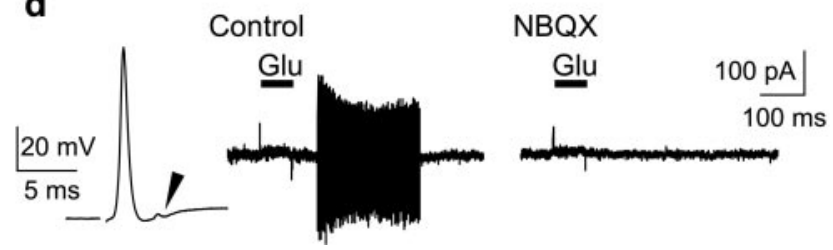

Figure 4. Activation of $I_{\text {glu }}$ by exogenous glutamate in bipolar cell terminals but not the calyx of Held. $a$, Puff application of $\mathrm{L}-$ glutamate $(10 \mathrm{~mm})$ to a bipolar cell terminal at $-60 \mathrm{mV}$ with $\mathrm{CsNO}_{3}$ intracellular solution. Control response in the presence of NBQX (10 $\left.\mu \mathrm{M}\right), \mathrm{DL}-\mathrm{AP}-5(100$ $\mu \mathrm{M})$, picrotoxin $(50 \mu \mathrm{M})$, strychnine $(1 \mu \mathrm{M})$, and $\mathrm{CdCl}_{2}(1 \mathrm{mM}) . b$, The $I-V$ relationship of $I_{\text {glu }}$ in one terminal. A protocol comprising brief incremental voltage steps from $-90 \mathrm{mV}$ was delivered both before glutamate application and at the peak of the response, and the $I-V$ curve obtained from the difference in the evoked currents at each potential. This recording was made with the addition of the mGluR antagonists MCPG $(500 \mu \mathrm{M})$ and CPPG $(200 \mu \mathrm{M})$ and the GLT1 antagonist DHK (200 $\mu \mathrm{m})$ to the extracellular solution. c, A glutamate response in the presence of the broad-spectrum glutamate transporter inhibitor TBOA $(50 \mu \mathrm{m})$ and the average peak $I_{\text {glu }}$ amplitudes for control $(n=6)$ and TBOA $(50 \mu \mathrm{m} ; n=6)$ recordings. Only the first response from each terminal used as substantial rundown was observed for subsequent responses $\left({ }^{*} p<\right.$ 0.05 compared with control). $d$, Electrophoretic application of L-glutamate $(0.5 \mathrm{M})$ to the calyx of Held (P11) at $-80 \mathrm{mV}$ with $\mathrm{KNO}_{3}$ intracellular solution. Left, Presynaptic action potential with "postpotential" marked by arrowhead, presumably arising from capacitively coupled activity in the postsynaptic neuron. Similarly, postsynaptic spikes evoked by L-glutamate application were observed in the presynaptic recording (middle). Postsynaptic activity was blocked by NBQX ( 5 $\mu \mathrm{M})$, leaving no presynaptic L-glutamate-evoked current (right).

of $-241 \pm 69 \mathrm{pA}\left(V_{\mathrm{h}}=-60 \mathrm{mV} ; n=6\right)$ (Fig. $\left.4 a\right)$. The currentto-voltage relationship of $I_{\text {glu }}$ was investigated in two terminals by varying $V_{\mathrm{h}}$ between -90 and $+90 \mathrm{mV}$ at the peak of the glutamate response and subtracting the current induced by the same voltage protocol before glutamate application. $I_{\text {glu }}$ exhibited an inwardly rectifying $I-V$ curve (Fig. $4 b$ ). This relationship is similar to that reported for glutamate transporter currents evoked in photoreceptors and retinal glial cells (Sarantis et al., 1988; Tachibana and Kaneko, 1988; Schwartz and Tachibana, 1990; Barbour et al., 1991). The sensitivity of $I_{\text {glu }}$ to glutamate transporter inhibitors was therefore examined. In the presence of the specific, nontransportable blocker TBOA $(50 \mu \mathrm{M})$ (Shimamoto et al., 1998; Shigeri et al., 2001), $I_{\text {glu }}$ was significantly inhibited $(-17 \pm$ $5 \mathrm{pA} ; n=6 ; p<0.05$ ) (Fig. $4 c$ ). However, the nontransportable GLT1/EAAT2 subtype-specific antagonist DHK $(200 \mu \mathrm{M})$ did not inhibit $I_{\text {glu }}(-348 \pm 101 \mathrm{pA} ; n=4)$.

For comparison, L-glutamate $(0.5 \mathrm{M})$ was applied electro- a
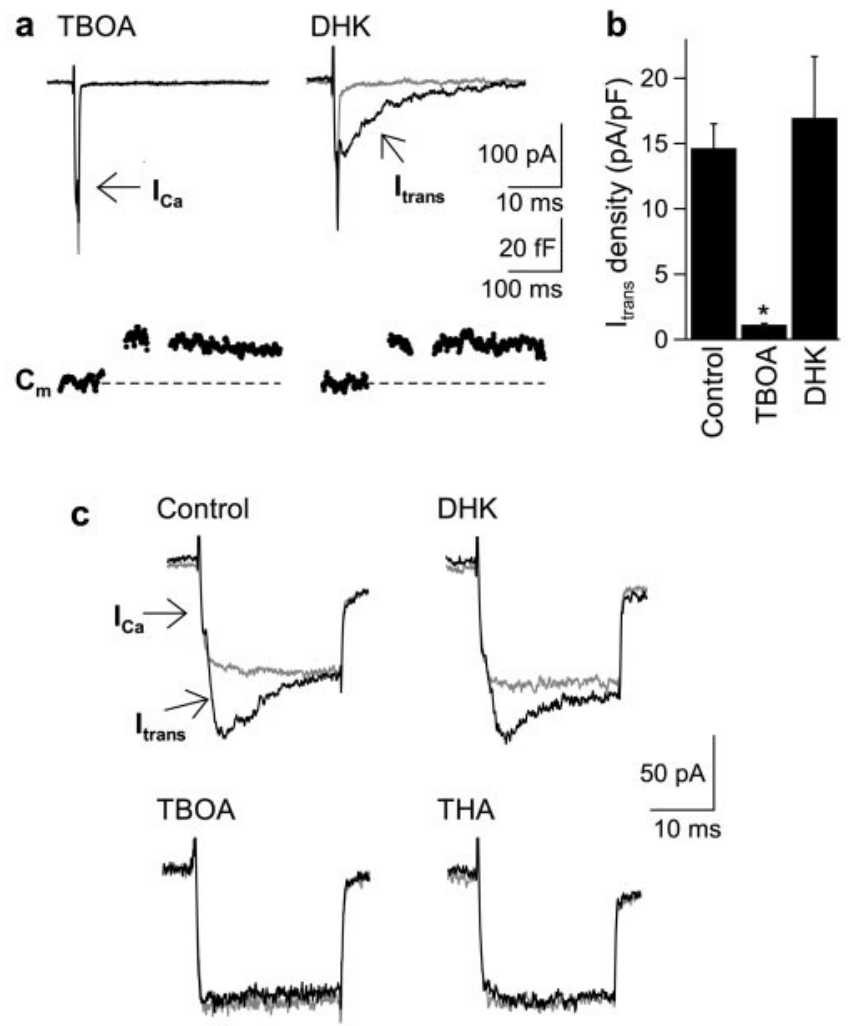

Figure 5. Sensitivity of $I_{\text {trans }}$ in bipolar cell terminals to glutamate transporter inhibitors. $a$, Superimposition of a pair of currents (first, black; second, gray) evoked by 1 msec depolarizations to $0 \mathrm{mV}$ (100 msec interval) in the presence of TBOA (50 $\mu \mathrm{m})$ or DHK $(500 \mu \mathrm{m}) . I_{\text {trans }}$ was observed with DHK but not with TBOA. Bottom, $\Delta C_{m}$ evoked by the first and second depolarizations, delivered during intervals in $C_{\mathrm{m}}$ trace, for these responses. $b$, Mean peak $I_{\text {trans }}$ amplitude normalized to terminal size for control $(n=10), \operatorname{TBOA}(50 \mu \mathrm{m} ; n=6)$, and DHK (500 $\mu \mathrm{m}$; $n=7$ ) responses. ${ }^{*} p<0.05$ compared with control. c, Superimposition of the membrane currents evoked by pairs of 25 msec depolarizations to $-30 \mathrm{mV}$ (100 msec interval; first, black; second, gray). $I_{\text {trans }}$ was observed during the first depolarization under control conditions and in the presence of DHK $(500 \mu \mathrm{m})$ but not in TBOA $(50 \mu \mathrm{m})$ or THA $(200 \mu \mathrm{M})$.

phoretically to the calyx of Held $\left(\mathrm{KNO}_{3}\right.$ intracellular solution; $V_{\mathrm{h}}=-80 \mathrm{mV}$ ). Recordings were confirmed as presynaptic by the action potential waveform evoked by afferent fiber stimulation (Borst et al., 1995) (Fig. 4d). In the presence of NBQX (5 $\mu \mathrm{M})$, an antagonist of the low-affinity AMPA-type glutamate receptor, no current was evoked by L-glutamate (Fig. $4 d$ ). In the absence of NBQX, high-frequency capacitively coupled spikes originating from action potential firing in the postsynaptic cell were recorded, confirming that L-glutamate was delivered to the synapse $(n=12)$ (Fig. $4 d)$. Interestingly, using the same electrophoretic procedure in the presence of NBQX $(5 \mu \mathrm{M})$ and D-AP-5 $(50 \mu \mathrm{M})$, prominent anion currents were observed in surrounding glial cells ( $\mathrm{H}$. Taschenberger and H. von Gersdorff, unpublished observations).

$I_{\text {trans }}$ has the pharmacological profile of a transporter current Because the glutamate-evoked current in bipolar cell terminals was significantly inhibited by the glutamate transporter antagonist TBOA, the sensitivity of $I_{\text {trans }}$ to transporter antagonists was investigated. TBOA $(50 \mu \mathrm{M})$ or DHK $(500 \mu \mathrm{M})$ was bath-applied in the presence of ionotropic glutamate receptor antagonists (10 $\mu \mathrm{M}$ NBQX, $100 \mu \mathrm{M}$ DL-AP-5). $I_{\text {trans }}$ was evoked by a pair of $1 \mathrm{msec}$ depolarizations to $0 \mathrm{mV}$. In the presence of TBOA, $I_{\text {trans }}$ was inhibited significantly (Fig. 5a). Current amplitude measured 
2-3 msec after the depolarization was $-3.8 \pm 0.2 \mathrm{pA}(n=6)$, compared with a peak $I_{\text {trans }}$ amplitude of $-54.9 \pm 7.3 \mathrm{pA}$ under control conditions $(n=10 ; p<0.05)$. The amount of glutamate release in the presence of TBOA, as measured by $\Delta C_{\mathrm{m}}$, was not significantly different from control experiments (control, $15.3 \pm$ $3.2 \mathrm{fF}, n=10$; TBOA, $17.6 \pm 3.9 \mathrm{fF}, n=6$ ) (Fig. $5 a$ ). The block by TBOA of the current evoked by a $1 \mathrm{msec}$ depolarization suggests that it is mediated solely by glutamate transporters, with no significant contribution from $\mathrm{Ca}^{2+}$-activated conductances. In contrast to TBOA, DHK (500 $\mu \mathrm{M})$ had no inhibitory effect on either the amplitude of $I_{\text {trans }}(-54.5 \pm 13.8 \mathrm{pA} ; n=7)$ (Fig. $\left.5 a\right)$ or the rate of decay $(7.2 \pm 0.9 \mathrm{msec} ; n=7)$. The peak amplitude of $I_{\text {trans }}$ was also normalized to baseline $C_{\mathrm{m}}$ to control for variability in terminal size, and no significant difference was found between DHK and control experiments (control, $-14.6 \pm 1.9 \mathrm{pA} / \mathrm{pF}, n=$ 10; DHK, $-16.9 \pm 4.7$ pA/pF, $n=6$ ) (Fig. $5 b$ ). All subsequent $I_{\text {trans }}$ amplitudes will be expressed as current density.

Because bipolar cells generally respond to stimulation with graded and sustained membrane potential changes, the activation of $I_{\text {trans }}$ was investigated during longer depolarizations to a more physiologically relevant membrane potential. Release was evoked by a pair of $25 \mathrm{msec}$ pulses ( $100 \mathrm{msec}$ interval) from -60 to $-30 \mathrm{mV}$. Paired-pulse depression of release for $25 \mathrm{msec}$ depolarizations was difficult to measure with $\mathrm{CsNO}_{3}$ intracellular solution because of the slow decay of a $\mathrm{Ca}^{2+}$-dependent anion conductance after the pulse. However, with Cs-gluconate intracellular solution, $\Delta C_{\mathrm{m}}$ evoked by the second pulse was on average only $13 \pm 4 \%$ of that evoked by the first pulse $(n=7$, data not shown). Under control conditions, $I_{\text {trans }}$ was observed in addition to $I_{\mathrm{Ca}}$ during the first but not the second depolarization $(n=8)$ (Fig. $5 c$ ). The additional first pulse inward current peaked within $5 \mathrm{msec}$ of the start of the depolarization and decayed with a mean time constant of $8.7 \mathrm{msec}$ during the remainder of the pulse. Interestingly, it was found from $\Delta C_{\mathrm{m}}$ measurements that the rate of release during a $25 \mathrm{msec}$ pulse decreases rapidly after the first millisecond, such that $\sim 87 \%$ of the total release occurs within the first 5 msec. $I_{\text {trans }}$ was evoked in the presence of DHK (500 $\mu \mathrm{M}$; $n=4$ ) (Fig. $5 c$ ) but was not observed in the presence of TBOA (50 $\mu \mathrm{M} ; n=6$ ) (Fig. $5 c$ ) or the substrate glutamate transporter inhibitor THA (200-300 $\mu \mathrm{M} ; n=7)$ (Fig. $5 c$ ).

Homologs of EAAT2, 3, and 5 have been localized to retinal bipolar cells by staining with specific antibodies (Rauen and Kanner, 1994; Schultz and Stell, 1996; Eliasof et al., 1998; Reye et al., 2002). Of these, GLT1/EAAT2 (Rauen et al., 1996; Vandenbranden et al., 2000) and EAAT5 (Pow and Barnett, 2000) have been localized specifically to bipolar cell terminals. Given the insensitivity of $I_{\text {trans }}$ to GLT1-specific DHK, the synaptically activated transporter current in bipolar cell terminals is likely to be mediated by a homolog of EAAT5.

\section{$I_{\text {trans }}$ is an anion current}

Transporter currents can be produced by both electrogenic uptake and an associated anion conductance. The anion conductance is more permeable to $\mathrm{NO}_{3}{ }^{-}$than $\mathrm{Cl}^{-}$and is impermeable to gluconate ${ }^{-}$(Wadiche et al., 1995). Intracellular $\mathrm{CsNO}_{3}$ was therefore replaced with Cs-gluconate to isolate electrogenic current. The $\Delta C_{\mathrm{m}}$ evoked by a $1 \mathrm{msec}$ depolarization with Csgluconate intracellular solution ( $13 \pm 2 \mathrm{fF} ; n=10)$ was comparable with that with $\mathrm{CsNO}_{3}$ solution, but $I_{\text {trans }}$ was never observed $(n=10)$ (Fig. $6 a)$, indicating a requirement for permeant anions. Consistent with this, $I_{\text {trans }}$ was evoked by a 1 msec depolarization with $\mathrm{CsCl}$ intracellular solution (Fig. 6a). The current had a peak amplitude of $-7.7 \pm 0.8 \mathrm{pA} / \mathrm{pF}(n=4)$, smaller than $\mathrm{CsNO}_{3}$
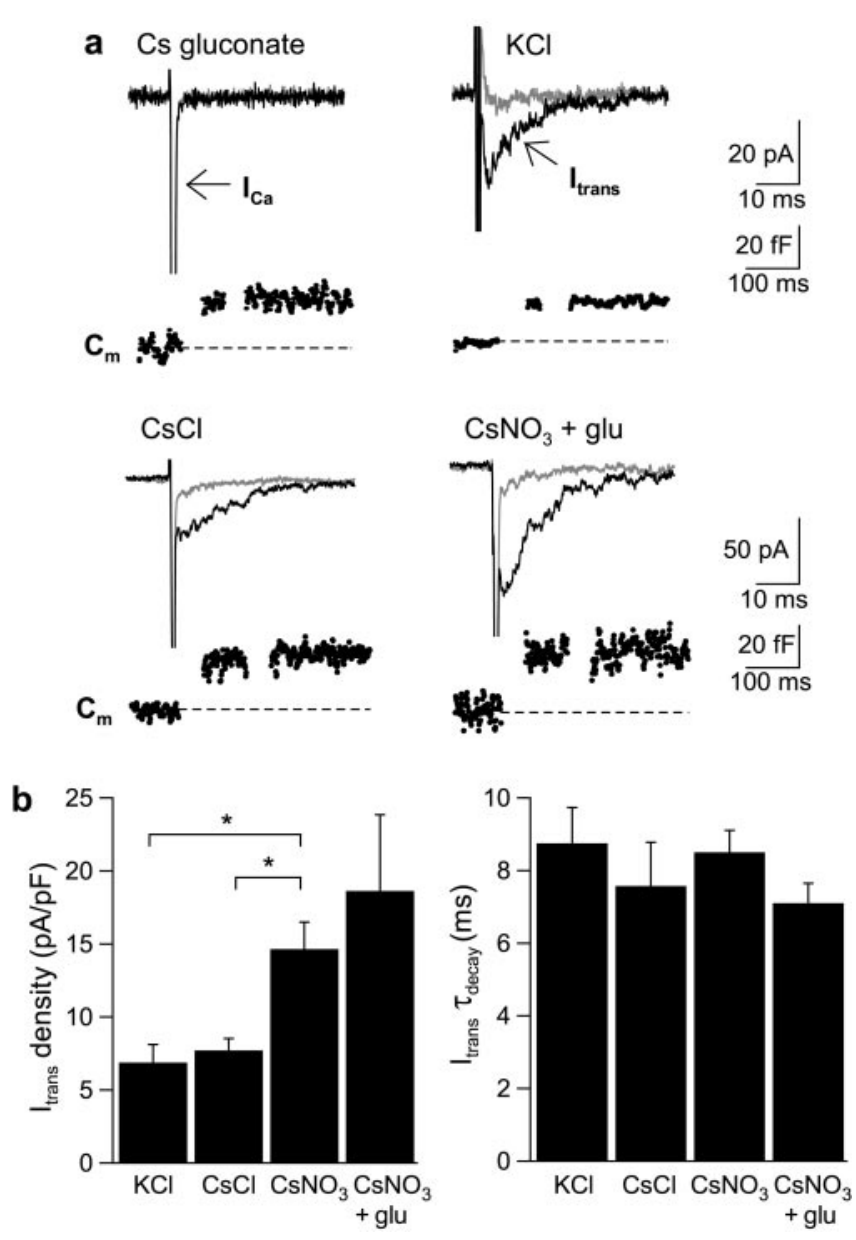

Figure 6. Ion selectivity of $I_{\text {trans }} \cdot a$, Currents evoked by a pair of 1 msec depolarizations to 0 $\mathrm{mV}$, superimposed (first, black; second, gray) with (bottom) $\Delta C_{m}$ evoked by the first and second depolarizations, delivered during intervals in $C_{m}$ trace. $I_{\text {trans }}$ was not observed with Cs gluconate but was evoked with either $\mathrm{KCl}$ or $\mathrm{CsCl}$ intracellular solution. Also shown is a recording with $\mathrm{CsNO}_{3}$ intracellular solution, which contained $10 \mathrm{~mm}$ L-glutamate. $b$, Comparison of mean $I_{\text {trans }}$ amplitude and $\tau_{\text {decay }}$ with $\mathrm{KCl}(n=4), \mathrm{CsCl}(n=4), \mathrm{CsNO}_{3}(n=10)$, or $\mathrm{CsNO}_{3}$ plus L-glutamate $(n=4)$ intracellular solution. ${ }^{*} p<0.05$.

recordings $(-14.6 \pm 1.9 \mathrm{pA} / \mathrm{pF})$, but the rate of decay of $I_{\text {trans }}$ was similar (7.6 $\pm 1.2 \mathrm{msec} ; n=4)$ (Fig. $6 b$ ).

Glutamate uptake is coupled to the countertransport of intracellular $\mathrm{K}^{+}$(Zerangue and Kavanaugh, 1996; Levy et al., 1998), which was normally replaced in our recordings by $\mathrm{Cs}^{+}$. It was found previously that glutamate-evoked anion currents in cells expressing the GLT1 subtype of glutamate transporter are significantly reduced by substitution of $\mathrm{K}^{+}$with $\mathrm{Cs}^{+}$(Bergles et al., 2002), and intracellular $\mathrm{Cs}^{+}$was shown to decrease transporter currents in isolated Müller cells by one-third (Barbour et al., 1991). Recordings of $I_{\text {trans }}$ in bipolar cell terminals were therefore also made with a KCl-based intracellular solution (Fig. 6a). The peak amplitude of $I_{\text {trans }}$ evoked by a $1 \mathrm{msec}$ depolarization was $-6.9 \pm 1.2 \mathrm{pA} / \mathrm{pF}(n=4)$ (Fig. $6 b)$, not significantly different from $\mathrm{CsCl}$ recordings. The rate of decay of $I_{\text {trans }}$ was also unaffected by $\mathrm{K}^{+}(8.8 \pm 1.0 \mathrm{msec} ; n=49)$ (Fig. $\left.6 b\right)$.

Under physiological conditions, glutamate transporters are working against a high cytoplasmic glutamate concentration, which will be lost during whole-cell recording. To determine whether this affected the size or kinetics of $I_{\text {trans }}$, experiments were also performed with a $\mathrm{CsNO}_{3}$-based intracellular solution that contained $10 \mathrm{~mm}$ L-glutamate. This did not change signifi- 
a

3 mM HEPES

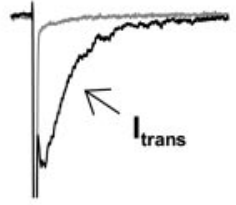

4 t thatip

$\mathrm{C}_{\mathrm{m}}$

b

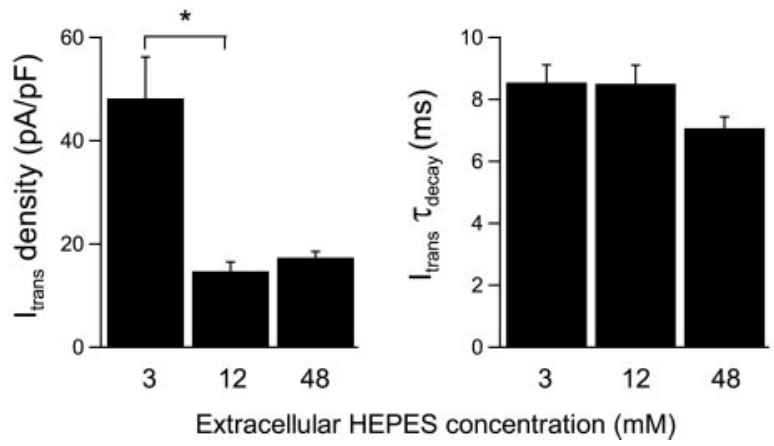

Figure 7. The effect of extracellular HEPES concentration on $I_{\text {trans }}$. $a$, Currents evoked by a pair of $1 \mathrm{msec}$ depolarizations to $0 \mathrm{mV}$, superimposed (first, black; second, gray) in the presence of 3 or $48 \mathrm{~mm}$ extracellular HEPES. $I_{\text {trans }}$ was greatly potentiated in low HEPES. Bottom, $\Delta C_{\mathrm{m}}$ evoked by the first and second depolarizations, delivered during intervals in $C_{\mathrm{m}}$ trace. $b$, Comparison of mean $I_{\text {trans }}$ amplitude and $\tau_{\text {decay }}$ with $3(n=5), 12(n=10)$, and $48(n=3) \mathrm{mM}$ extracellular HEPES. ${ }^{*} p<0.05$.

cantly either the peak amplitude $(-18.6 \pm 5.2 \mathrm{pA} / \mathrm{pF} ; n=4)$ or rate of decay $(7.1 \pm 0.5 \mathrm{msec} ; n=4)$ of $I_{\text {trans }}$ evoked by a $1 \mathrm{msec}$ depolarization (Fig. 6a,b).

\section{$I_{\text {trans }}$ is augmented in low extracellular $\mathrm{pH}$ buffer}

After exocytosis, the synaptic cleft is transiently acidified because of the low pH of synaptic vesicles (Krishtal et al., 1987; Miesenböck et al., 1998). This may affect transporter function, because protons are cotransported during glutamate uptake (Zerangue and Kavanaugh, 1996). The magnitude of synaptic cleft acidification can be modulated by exogenous pH buffers (DeVries, 2001); therefore, the effect of extracellular HEPES on the transporter current was investigated. The concentration of HEPES in the extracellular solution was changed from 12 to 3 or $48 \mathrm{~mm}$ by substitution with $\mathrm{NaCl}$, and the $\mathrm{pH}$ was set to 7.45 with $\mathrm{NaOH}$ solution. The final $\mathrm{Na}^{+}$concentration ranged from $105 \mathrm{~mm}$ (with 48 mM HEPES) to $130 \mathrm{~mm}$ (with 3 mM HEPES). This difference in $\mathrm{Na}^{+}$concentration should not greatly affect the current, because both are near saturation for the effect of $\mathrm{Na}^{+}$on transporter function. We confirmed this by using a recent model of glutamate transporter function (Bergles et al., 2002), which showed that this difference in $\mathrm{Na}^{+}$concentration affected the transporter current by a maximum of $4-9 \%$ (using $100 \mu \mathrm{M}$ to 100 mM L-glutamate pulses; C. E. Jahr, personal communication). $I_{\text {trans }}$ was evoked by a pair of $1 \mathrm{msec}$ depolarizations to $0 \mathrm{mV}$ with $\mathrm{CsNO}_{3}$ intracellular solution. When the extracellular HEPES concentration was increased from 12 to $48 \mathrm{~mm}$, neither the amplitude nor the decay of $I_{\text {trans }}$ was altered significantly $(-17.3 \pm$ $1.2 \mathrm{pA} / \mathrm{pF} ; 7.1 \pm 0.4 \mathrm{msec} ; n=3$ ) (Fig. $7 a, b)$. However, lowering the HEPES concentration from 12 to $3 \mathrm{~mm}$ caused a $230 \%$ increase in the amplitude of $I_{\text {trans }}$ to $-48.2 \pm 8.0 \mathrm{pA} / \mathrm{pF}(n=5 ; p<$ $0.05)$ (Fig. $7 a, b)$, with no change in the rate of decay $(8.5 \pm 0.6$ msec) (Fig. 7b). There was no significant difference in $I_{\mathrm{Ca}}$ or $\Delta C_{\mathrm{m}}$
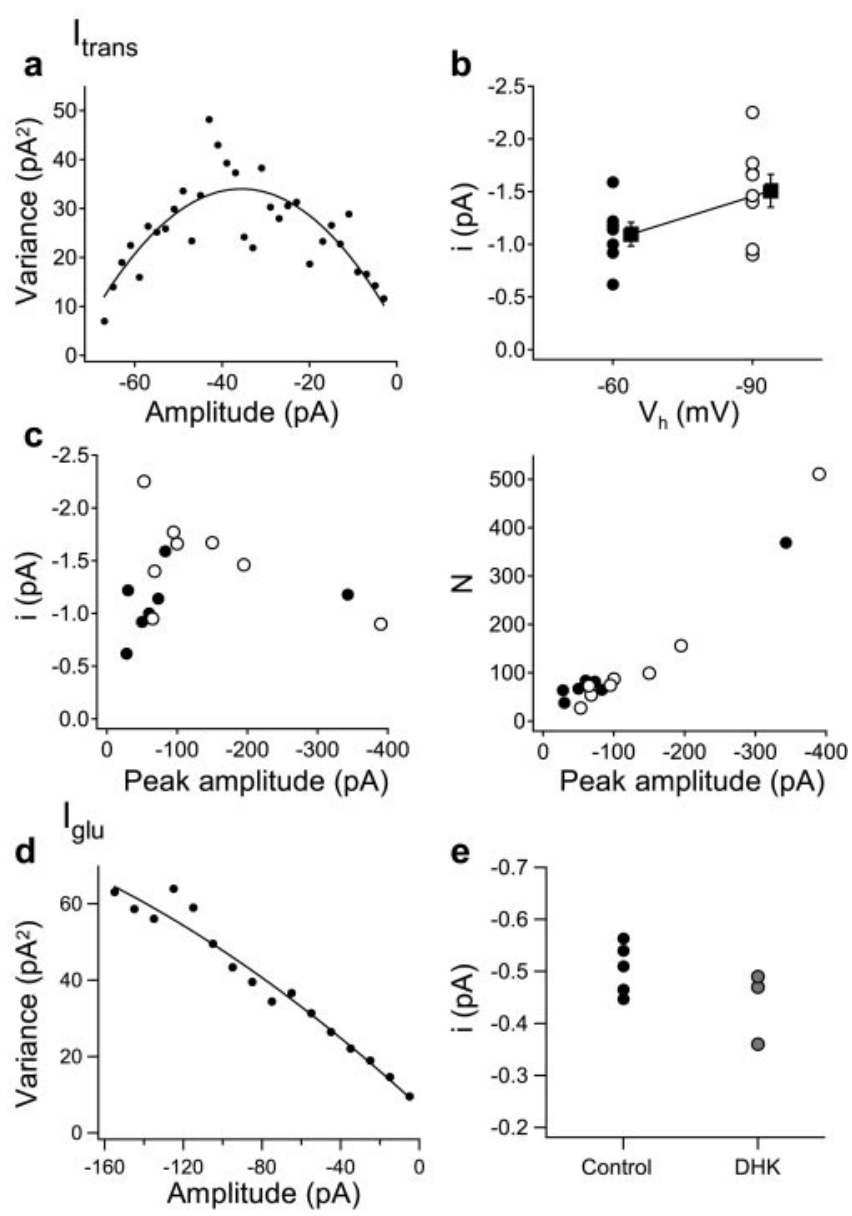

Figure 8. Peak-scaled nonstationary noise analysis of the decay of $I_{\text {trans }}$ evoked by $1 \mathrm{msec}$ depolarizations to $0 \mathrm{mV}$ and nonstationary noise analysis of the decay of $I_{\text {glu }} \cdot a$, Variance $\left(\sigma^{2}\right)$ versus amplitude $(I)$ plot for $I_{\text {trans }}$ in one terminal and fit of the data by $\sigma^{2}=i l-I^{2} / N+b_{1}$ to yield estimates for $i$ (single-channel current) and $N$ (average number of channels open at peak of response). For this terminal, $i$ was $-1.4 \mathrm{pA}$ and $N$ was $45 . b$, Values of $i$ obtained for individual terminals at a holding potential $\left(V_{\mathrm{h}}\right)$ of -60 or $-90 \mathrm{mV}$ (closed/open circles) and mean \pm SEM (gray squares). c, Plot of $i$ (left) and $N$ (right) against mean peak amplitude of $I_{\text {trans }}$ for each terminal (closed circles, $-60 \mathrm{mV}$; open circles, $-90 \mathrm{mV}$ ). $d$, Variance versus amplitude plot for $I_{\text {glu }}$ in one terminal and fit of the data by $\sigma^{2}=i l-I^{2} / N+b_{1}$. For this response, $i$ was $-0.5 \mathrm{pA}$ and $N$ was 1486 . $e$, Values of $i$ obtained from $I_{\text {glu }}$ for individual terminals under control conditions and in the presence of DHK (200 $\mu \mathrm{M})$.

evoked by 1 msec depolarizations between recordings with 3 and $48 \mathrm{~mm}$ extracellular HEPES (Fig. 7a), indicating that the increase in $I_{\text {trans }}$ was not a result of increased glutamate release.

\section{$I_{\text {trans }}$ has a large single-channel current}

The permeability of transporter-associated anion channels is known to differ between transporter subtypes, with EAAT4 and 5 displaying a much larger anion current than EAAT1 or 2 (Fairman et al., 1995; Arriza et al., 1997; Eliasof et al., 1998). The $\mathrm{Cl}^{-}$ conductance of the anion channel associated with EAAT1 was found to be at the subfemtosiemens level (Wadiche and Kavanaugh, 1998), whereas a value of $0.7 \mathrm{pS}$ was obtained for glutamate transporters in photoreceptors (Picaud et al., 1995b; Larsson et al., 1996). To investigate the anion conductance of glutamate transporters in bipolar cell terminals, an estimate of single-channel current was obtained by noise analysis of the transporter currents. Peak-scaled nonstationary noise analysis was applied to the decay of $I_{\text {trans }}$ using a method described previously for postsynaptic currents (Traynelis et al., 1993; Benke et 
al., 1998). $I_{\text {trans }}$ was evoked by $1 \mathrm{msec}$ depolarizations to $0 \mathrm{mV}$ with $\mathrm{CsNO}_{3}$ intracellular solution. $\mathrm{Ca}^{2+}$-activated conductances are unlikely to contribute significant noise to the decay of $I_{\text {trans, }}$, because current variance after the pulse in the presence of TBOA $\left(1.9 \pm 0.3 \mathrm{pA}^{2}\right)$ was not significantly greater than baseline variance $\left(1.4 \pm 0.4 \mathrm{pA}^{2} ; n=6\right)$. For each terminal, a plot of mean current variance against amplitude gave estimates for singlechannel current $(i)$ and the average number of channels open at the peak of the current $(N)$ (Fig. $8 a$ ). At a $V_{\mathrm{h}}$ of $-60 \mathrm{mV}$, an average value of $-1.1 \pm 0.1 \mathrm{pA}$ was obtained for $i(n=7$, Fig. $8 b)$. As a control, $I_{\text {trans }}$ was recorded in a different set of terminals at $-90 \mathrm{mV}$ and yielded a value for $i$ of $-1.5 \pm 0.2 \mathrm{pA}(n=8)$ (Fig. $8 b$ ), consistent with the increased driving force at this membrane potential. There was considerable variability in the peak amplitude of $I_{\text {trans }}$ between recordings. For a constant $V_{\mathrm{h}}$, larger macroscopic currents were associated with an increase in $N$ but not with an increase in $i$ (Fig. $8 c$ ). From the single-channel current values obtained at -60 and $-90 \mathrm{mV}$, the slope conductance between these potentials is $13.3 \mathrm{pS}$.

An estimate of $i$ was also obtained by noise analysis of the currents evoked by application of exogenous glutamate $\left(I_{\mathrm{glu}}\right)$ to bipolar cell terminals. A current variance/amplitude plot for the decay of each response (Fig. $8 d$ ) yielded a mean value for $i$ of $-0.51 \pm 0.02 \mathrm{pA}$ at $-60 \mathrm{mV}$ ( $n=5$ terminals) (Fig. $8 e$ ). The lower single-channel current value obtained by noise analysis of $I_{\text {glu }}$ could result from the activation of different populations of transporters by the two techniques. For example, application of exogenous glutamate could also activate GLT1-type transporters, which have been identified at a distance from synaptic ribbons in goldfish bipolar cell terminals (Vandenbranden et al., 2000) and have a much smaller associated anion conductance than EAAT5 (Eliasof et al., 1998). However, noise analysis of $I_{\text {glu }}$ evoked in the presence of DHK $\left(200 \mu \mathrm{M}\right.$; GLT1 $\left.K_{\mathrm{m}}=8-53 \mu \mathrm{M}\right)$ (Levy et al., 1998; Chen et al., $2002)$ gave a single-channel current value of $-0.44 \pm 0.04 \mathrm{pA}$ ( $n=3$ terminals) (Fig. $8 e$ ), which was not significantly different from control recordings. GLT1-like transporters are therefore unlikely to contribute greatly to $I_{\text {glu }}$.

\section{Discussion}

\section{Glutamate transporter currents are observed in bipolar cell terminals}

Our results demonstrate the activation of a previously unreported presynaptic current by very brief depolarization of isolated bipolar cell terminals in retinal slices. Several lines of evidence identify this as a glutamate transporter-associated current. First, current amplitude correlated with the amount of glutamate released, as measured by $\Delta C_{\mathrm{m}}$, during both paired-pulse depression and rundown of release. Second, the current was not observed with gluconate as the major intracellular anion and was larger with $\mathrm{NO}_{3}{ }^{-}$than $\mathrm{Cl}^{-}$. It is unlikely to reflect activation of the $\mathrm{Ca}^{2+}$-dependent $\mathrm{Cl}^{-}$current expressed in bipolar cell terminals (Okada et al., 1995), because the amplitude of this current correlates directly with $\mathrm{Ca}^{2+}$ influx (Burrone et al., 2002) and is therefore not depressed by the paired-pulse protocol. Third, it was inhibited by the glutamate transporter antagonists TBOA and THA. In addition, a TBOA-sensitive current was evoked in bipolar cell terminals by application of exogenous glutamate in the presence of antagonists of $\mathrm{Ca}^{2+}$ channels, glutamate, GABA and glycine ionotropic receptors, and mGluRs. The pharmacology and large single-channel anion current of the transporter suggest that it is the EAAT5 subtype, which has been found to be strongly immunolocalized to rat bipolar cell terminals (Pow and Barnett, 2000).

In photoreceptors, glutamate uptake currents have also been found to arise in the synaptic terminal (Sarantis et al., 1988; Eliasof and Werblin, 1993; Picaud et al., 1995a; Grant and Werblin, 1996). Both photoreceptors and bipolar cells release glutamate from ribbon-type synapses. The expression of presynaptic glutamate transporters may therefore be related to the high capacity and rates of release attainable at these synapses (Mennerick and Matthews, 1996; von Gersdorff et al., 1996). Glutamate uptake has been reported to modulate postsynaptic responses at both the photoreceptor-to-bipolar cell (Vandenbranden et al., 1996; Gaal et al., 1998) and bipolar cell-to-ganglion cell synapses (Higgs and Lukasiewicz, 1999; Matsui et al., 1999; Chen and Diamond, 2002). It is likely that at least part of this uptake occurs via presynaptic transporters.

\section{Glutamate transporter currents are absent from the calyx of Held}

Glutamate transporters contribute to shaping the time course of postsynaptic currents and limit the effects of glutamate spillover at various conventional active zone synapses (Barbour et al., 1994; Tong and Jahr, 1994; Takahashi et al., 1995; Otis et al., 1996; Overstreet et al., 1999; Diamond, 2001; Arnth-Jensen et al., 2002), including the calyx of Held (Taschenberger and von Gersdorff, 2001). The major neuronal glutamate transporter (EAAC1/EAAT3) has been localized to presynaptic terminals in some brain regions (Rothstein et al., 1994; Furuta et al., 1997a; He et al., 2000; Chen et al., 2002) but is absent from others (Conti et al., 1998). In the present study, no presynaptic transporter current was identified in the calyx of Held. Recordings were made from terminals during the maturation phase of the synapse (P5P14). Because the expression of glutamate transporters is regulated developmentally (Furuta et al., 1997b), it remains possible that presynaptic transporters may be present in adult animals. Our results, together with an absence of evoked glutamate transporter current in postsynaptic MNTB neurons (Taschenberger and von Gersdorff, unpublished observations), suggest that glutamate transporters may be expressed exclusively in glial cells at the calyx of Held synapse.

\section{Transporter currents in bipolar cell terminals have fast kinetics}

The transporter current evoked by a $1 \mathrm{msec}$ stimulation peaked $2.8 \mathrm{msec}$ after the onset of the depolarizing pulse and decayed with a time constant of $8.5 \mathrm{msec}$. Postsynaptic transporterassociated anion currents evoked by synaptically released glutamate in cerebellar Purkinje cells were reported to have much slower kinetics (Otis et al., 1997; Auger and Attwell, 2000). This may result from transporter localization at a distance from release sites because brief glutamate application to excised membrane patches evoked currents with faster kinetics (decay time constant of $7.8 \mathrm{msec}$ for $1 \mathrm{msec}$ application) (Otis et al., 1997). It is unknown how the decay time of glutamate transporter currents in bipolar cell terminals in situ is affected by the rate of glutamate diffusion or the possible presence of postsynaptic transporters with fast kinetics. However, the relatively fast time course of the recorded current suggests that glutamate clearance from the vicinity of the transporters is fairly rapid. Interestingly, the rate of decay of $I_{\text {trans }}$ was unaffected by GLT1 antagonists. It is also unclear how the time course of the anion current is related to the kinetics of glutamate uptake by a transporter. It has been suggested that the anion current is activated on glutamate binding 
and deactivates as the transporter moves into subsequent conformational states (Otis and Jahr, 1998). The anion and electrogenic currents were found to have a similar time course for EAAT2 (Otis and Kavanaugh, 2000), but the anion current exhibited slower kinetics than the electrogenic current for GLT1 (Bergles et al., 2002). Similarly, the transporter-associated anion current activated by synaptically released glutamate in Purkinje cells was reported to have a much slower time course than the electrogenic current (Auger and Attwell, 2000). In bipolar cell terminals, electrogenic uptake currents were not detected in the absence of permeant anions, and it was therefore difficult to determine the relationship between the recorded current and glutamate transport.

\section{Transporter currents in bipolar cell terminals are potentiated by low $\mathrm{pH}$}

The amplitude of bipolar cell terminal transporter currents was increased significantly by reducing the concentration of extracellular $\mathrm{pH}$ buffer, which will lead to an increase in synaptic cleft acidification after exocytosis (DeVries, 2001). The effect of extracellular protons on glutamate transporter function is likely to be complex. Consistent with the cotransport of protons and glutamate, alkalization of the extracellular medium has been shown to reduce steady-state transporter currents evoked by glutamate (Zerangue and Kavanaugh, 1996; Watzke et al., 2000), although glutamate transport can also be inhibited by acidification (Billups and Attwell, 1996). Synaptically activated transporter currents in the cerebellum were unaffected by elevated $\mathrm{pH}$, although steady-state currents were significantly depressed in the same cells (Auger and Attwell, 2000). The transporter-associated anion conductance may also be modulated directly by $\mathrm{pH}$ (Watzke et al., 2000), and there is evidence for an additional proton current associated with EAAT4, which is potentiated by arachidonic acid (Fairman et al., 1998; Tzingounis et al., 1998). The exact role of protons in transporter function therefore remains uncertain and additional work is necessary to determine how bipolar cell transporter currents are potentiated by low $\mathrm{pH}$.

\section{Possible function of glutamate transporters in bipolar cell terminals}

Assuming a single-channel current of $-1.1 \mathrm{pA}$ and a 1:1 transporter-to-anion channel ratio, we estimate that the glutamate released by a $1 \mathrm{msec}$ depolarization activates, on average, $\sim 50$ transporters $(-55 /-1.1 \mathrm{pA})$. This is a surprisingly small number, considering the associated $\Delta C_{\mathrm{m}}(15 \mathrm{fF})$, which indicates the release of $\sim 600$ vesicles. Given the large number of active zones per terminal ( 55) (von Gersdorff et al., 1996), it suggests that transporters are not expressed at high density in the immediate vicinity of release sites. It also suggests a role for presynaptic transporters with high anion permeability in rapid signaling mechanisms. Bipolar cell terminals have a low endogenous $\mathrm{Cl}^{-}$ concentration $(\sim 23 \mathrm{~mm})$, resulting in outward current through $\mathrm{Cl}^{-}$channels at physiological membrane potentials (Billups and Attwell, 2002). Assuming a Cl${ }^{-}$reversal potential of $-60 \mathrm{mV}$ and a single-channel conductance of $9 \mathrm{pS}$ (estimated from the amplitude of $I_{\text {trans }}$ with CsCl or $\mathrm{KCl}$ intracellular solution), an outward current of $\sim 14$ pA would result from the activation of 50 transporters at $-30 \mathrm{mV}$. This would equate to a membrane hyperpolarization of $7 \mathrm{mV}$ with $0.5 \mathrm{G} \Omega$ input resistance (Protti et al., 2000). This is likely to be an underestimate, because physiological $\mathrm{pH}$ buffering conditions are more similar to $3 \mathrm{~mm}$ than $12 \mathrm{~mm}$ extracellular HEPES (M. J. Palmer and H. von Gersdorff, unpub- lished observations). Future studies will aim to determine the function of this $\mathrm{Cl}^{-}$current in bipolar cell terminals. In photoreceptors, it was found that activation of a transporter-associated $\mathrm{Cl}^{-}$current by exogenous glutamate reduced $\mathrm{K}^{+}$-evoked depolarizations (Picaud et al., 1995a), and in bipolar cell dendrites, a similar glutamate-activated $\mathrm{Cl}^{-}$current has been suggested to contribute to light responses (Grant and Dowling, 1995).

Finally, we note that although the number of transporters activated by a brief depolarization seems to be small, these results do not preclude the existence of a large population of extrasynaptic glutamate transporters. From the amplitude of the largest glutamate-evoked transporter current $(-551 \mathrm{pA})$ and the singlechannel current obtained from this terminal $(-0.48 \mathrm{pA}),>1000$ EAAT5-type transporters may be present on bipolar cell terminals. Thus, in addition to being located strategically close to release sites for putative signaling purposes, transporters located extrasynaptically may serve a more traditional role in glutamate uptake. Presynaptic transporters may be necessary for glutamate clearance at this synapse, because Müller cells do not contact bipolar cell terminals directly (Pow and Barnett, 1999). We conclude that glutamate transporters in bipolar cell terminals may function to signal a fast hyperpolarization after phasic release and contribute to the reuptake process after tonic release from this ribbon-type synapse.

\section{References}

Arnth-Jensen N, Jabaudon D, Scanziani M (2002) Cooperation between independent hippocampal synapses is controlled by glutamate uptake. Nat Neurosci 5:325-331.

Arriza JL, Eliasof S, Kavanaugh MP, Amara SG (1997) Excitatory amino acid transporter 5, a retinal glutamate transporter coupled to a chloride conductance. Proc Natl Acad Sci USA 94:4155-4160.

Auger C, Attwell D (2000) Fast removal of synaptic glutamate by postsynaptic transporters. Neuron 28:547-558.

Barbour B, Brew H, Attwell D (1991) Electrogenic uptake of glutamate and aspartate into glial cells isolated from the salamander (Ambystoma) retina. J Physiol (Lond) 436:169-193.

Barbour B, Keller BU, Llano I, Marty A (1994) Prolonged presence of glutamate during excitatory synaptic transmission to cerebellar Purkinje cells. Neuron 12:1331-1343.

Benke TA, Lüthi A, Isaac JTR, Collingridge GL (1998) Modulation of AMPA receptor unitary conductance by synaptic activity. Nature 393:793-797.

Bergles DE, Jahr CE (1997) Synaptic activation of glutamate transporters in hippocampal astrocytes. Neuron 19:1297-1308.

Bergles DE, Dzubay JA, Jahr CE (1997) Glutamate transporter currents in Bergmann glial cells follow the time course of extrasynaptic glutamate. Proc Natl Acad Sci USA 94:14821-14825.

Bergles DE, Tzingounis AV, Jahr CE (2002) Comparison of coupled and uncoupled currents during glutamate uptake by GLT-1 transporters. J Neurosci 22:10153-10162.

Billups B, Attwell D (1996) Modulation of non-vesicular glutamate release by $\mathrm{pH}$. Nature 379:171-174.

Billups D, Attwell D (2002) Control of intracellular chloride concentration and GABA response polarity in rat retinal ON bipolar cells. J Physiol (Lond) 545:183-198.

Billups B, Rossi D, Attwell D (1996) Anion conductance behavior of the glutamate uptake carrier in salamander retinal glial cells. J Neurosci 16:6722-6731.

Borst JG, Helmchen F, Sakmann B (1995) Pre- and postsynaptic whole-cell recordings in the medial nucleus of the trapezoid body of the rat. J Physiol (Lond) 489:825-840.

Burrone J, Lagnado L (2000) Synaptic depression and the kinetics of exocytosis in retinal bipolar cells. J Neurosci 20:568-578.

Burrone J, Neves G, Gomis A, Lagnado L (2002) Endogenous calcium buffers regulate fast exocytosis in the synaptic terminal of retinal bipolar cells. Neuron 33:101-112.

Chen S, Diamond JS (2002) Synaptically released glutamate activates extra- 
synaptic NMDA receptors on cells in the ganglion cell layer of rat retina. J Neurosci 22:2165-2173.

Chen W, Aoki C, Madadomrongkul V, Gruber CE, Wang GJ, Blitzblau R, Irwin N, Rosenberg PA (2002) Expression of a variant form of the glutamate transporter GLT1 in neuronal cultures and in neurons and astrocytes in the rat brain. J Neurosci 22:2142-2151.

Clark BA, Barbour B (1997) Currents evoked in Bergmann glial cells by parallel fibre stimulation in rat cerebellar slices. J Physiol (Lond) 502:335-350.

Conti F, Debiasi S, Minelli A, Rothstein JD, Melone M (1998) EAAC1, a high affinity glutamate transporter, is localized to astrocytes and GABAergic neurons besides pyramidal cells in the rat cerebral cortex. Cereb Cortex 8:108-116.

Danbolt NC (2001) Glutamate uptake. Prog Neurobiol 65:1-105.

DeVries SH (2001) Exocytosed protons feedback to suppress the $\mathrm{Ca}^{2+}$ current in mammalian cone photoreceptors. Neuron 32:1107-1117.

Diamond JS (2001) Neuronal glutamate transporters limit activation of NMDA receptors by neurotransmitter spillover on CA1 pyramidal cells. J Neurosci 21:8328-8338.

Eliasof S, Werblin F (1993) Characterization of the glutamate transporter in retinal cones of the tiger salamander. J Neurosci 13:402-411.

Eliasof S, Arriza JL, Leighton BH, Kavanaugh MP, Amara SG (1998) Excitatory amino acid transporters of the salamander retina: identification, localization, and function. J Neurosci 18:698-712.

Fairman WA, Vandenberg RJ, Arriza JL, Kavanaugh MP, Amara SG (1995) An excitatory amino-acid transporter with properties of a ligand-gated chloride channel. Nature 375:599-603.

Fairman WA, Sonders MS, Murdoch GH, Amara SG (1998) Arachidonic acid elicits a substrate-gated proton current associated with the glutamate transporter EAAT4. Nat Neurosci 1:105-113.

Forsythe ID, Barnes-Davies M (1993) The binaural auditory pathway: excitatory amino acid receptors mediate dual timecourse excitatory postsynaptic currents in the rat medial nucleus of the trapezoid body. Proc R Soc Lond B Biol Sci 251:151-157.

Furuta A, Martin LJ, Lin CLG, Dykes-Hoberg M, Rothstein JD (1997a) Cellular and synaptic localization of the neuronal glutamate transporters excitatory amino acid transporter 3 and 4. Neuroscience 81:1031-1042.

Furuta A, Rothstein JD, Martin LJ (1997b) Glutamate transporter protein subtypes are expressed differentially during rat CNS development. J Neurosci 17:8363-8375.

Gaal L, Roska B, Picaud SA, Wu SM, Marc R, Werblin FS (1998) Postsynaptic response kinetics are controlled by a glutamate transporter at cone photoreceptors. J Neurophysiol 79:190-196.

Gillis K (1995) Techniques for membrane capacitance measurements. In: Single-channel recording, Ed 2 (Sakmann B, Neher E, eds), pp 155-198. New York: Plenum.

Grant GB, Dowling JE (1995) A glutamate-activated chloride current in cone-driven ON bipolar cells of the white perch retina. J Neurosci 15:3852-3862.

Grant GB, Dowling JE (1996) ON bipolar cell responses in the teleost retina are generated by two distinct mechanisms. J Neurophysiol 76:3842-3849.

Grant GB, Werblin FS (1996) A glutamate-elicited chloride current with transporter-like properties in rod photoreceptors of the tiger salamander. Vis Neurosci 13:135-144.

Gundersen V, Danbolt NC, Ottersen OP, Storm-Mathisen J (1993) Demonstration of glutamate/aspartate uptake activity in nerve endings by use of antibodies recognizing exogenous D-aspartate. Neuroscience 57:97-111.

He Y, Janssen WG, Rothstein JD, Morrison JH (2000) Differential synaptic localization of the glutamate transporter EAAC1 and glutamate receptor subunit GluR2 in the rat hippocampus. J Comp Neurol 418:255-269.

Heidelberger R, Matthews G (1992) Calcium influx and calcium current single synaptic terminals of goldfish retinal bipolar neurons. J Physiol (Lond) 447:235-256.

Higgs MH, Lukasiewicz PD (1999) Glutamate uptake limits synaptic excitation of retinal ganglion cells. J Neurosci 19:3691-3700.

Krishtal OA, Osipchuk YV, Shelest TN, Smirnoff SV (1987) Rapid extracellular $\mathrm{pH}$ transients related to synaptic transmission in rat hippocampal slices. Brain Res 436:352-356.

Larsson HP, Picaud SA, Werblin FS, Lecar H (1996) Noise analysis of the glutamate-activated current in photoreceptors. Biophys J 70:733-742.

Levy LM, Warr O, Attwell D (1998) Stoichiometry of the glial glutamate transporter GLT-1 expressed inducibly in a Chinese hamster ovary cell line selected for low endogenous $\mathrm{Na}^{+}$-dependent glutamate uptake. J Neurosci 18:9620-9628.

Matsui K, Hosoi N, Tachibana M (1999) Active role of glutamate uptake in the synaptic transmission from retinal nonspiking neurons. J Neurosci 19:6755-6766.

Mennerick S, Matthews G (1996) Ultrafast exocytosis elicited by calcium current in synaptic terminals of retinal bipolar neurons. Neuron 17:1241-1249.

Mennerick S, Matthews G (1998) Rapid calcium-current kinetics in synaptic terminals of goldfish retinal bipolar neurons. Vis Neurosci 15:1051-1056.

Mennerick S, Zenisek D, Matthews G (1997) Static and dynamic membrane properties of large-terminal bipolar cells from goldfish retina: experimental test of a compartment model. J Neurophysiol 78:51-62.

Miesenböck G, De Angelis DA, Rothman JE (1998) Visualizing secretion and synaptic transmission with $\mathrm{pH}$-sensitive green fluorescent proteins. Nature 394:192-195.

Okada T, Horiguchi H, Tachibana M (1995) $\mathrm{Ca}^{2+}$-dependent $\mathrm{Cl}^{-}$current at the presynaptic terminals of goldfish retinal bipolar cells. Neurosci Res 23:297-303.

Otis TS, Jahr CE (1998) Anion currents and predicted glutamate flux through a neuronal glutamate transporter. J Neurosci 18:7099-7110.

Otis TS, Kavanaugh MP (2000) Isolation of current components and partial reaction cycles in the glial glutamate transporter EAAT2. J Neurosci 20:2749-2757.

Otis TS, Yuh-cherng W, Trussell LO (1996) Delayed clearance of transmitter and the role of glutamate transporters at synapses with multiple release sites. J Neurosci 16:1634-1644.

Otis TS, Kavanaugh MP, Jahr CE (1997) Postsynaptic glutamate transport at the climbing fiber-Purkinje cell synapse. Science 277:1515-1518.

Overstreet LS, Kinney GA, Liu Y-B, Billups D, Slater NT (1999) Glutamate transporters contribute to the time course of synaptic transmission in cerebellar granule cells. J Neurosci 19:9663-9673.

Picaud S, Larsson HP, Wellis DP, Lecar H, Werblin FS (1995a) Cone photoreceptors respond to their own glutamate release in the tiger salamander. Proc Natl Acad Sci USA 92:9417-9441.

Picaud S, Larsson HP, Grant GB, Lecar H, Werblin FS (1995b) Glutamategated chloride channel with glutamate-transporter-like properties in cone photoreceptors of the tiger salamander. J Neurophysiol 74:1760-1771.

Pow DV, Barnett NL (1999) Changing patterns of spatial buffering of glutamate in developing rat retinae are mediated by the Muller cell glutamate transporter GLAST. Cell Tissue Res 297:57-66.

Pow DV, Barnett NL (2000) Developmental expression of excitatory amino acid transporter 5: a photoreceptor and bipolar cell glutamate transporter in rat retina. Neurosci Lett 280:21-24.

Protti DA, Flores-Herr N, von Gersdorff H (2000) Light evokes $\mathrm{Ca}^{2+}$ spikes in the axon terminal of a retinal bipolar cell. Neuron 25:215-227.

Rauen T, Kanner BI (1994) Localization of the glutamate transporter GLT-1 in rat and macaque monkey retina. Neurosci Lett 169:137-140.

Rauen T, Rothstein JD, Wässle H (1996) Differential expression of three glutamate transporter subtypes in the rat retina. Cell Tissue Res 286:325-336.

Reye P, Sullivan R, Fletcher EL, Pow D (2002) Distribution of two splice variants of the glutamate transporter GLT1 in the retinas of humans, monkeys, rabbits, rats, cats and chickens. J Comp Neurol 445:1-12.

Rothstein JD, Martin L, Levey AI, Dykes-Hoberg M, Jin L, Wu D, Nash N, Kuncl RW (1994) Localization of neuronal and glial glutamate transporters. Neuron 13:713-725.

Sarantis M, Everett K, Attwell D (1988) A presynaptic action of glutamate at the cone output synapse. Nature 332:451-453.

Sätzler K, Söhl LF, Bollmann JH, Borst JGG, Frotscher M, Sakmann B, Lübke JHR (2002) Three-dimensional reconstruction of a calyx of Held and its postsynaptic principal neuron in the medial nucleus of the trapezoid body. J Neurosci 22:10567-10579.

Schultz K, Stell WK (1996) Immunocytochemical localization of the highaffinity glutamate transporter, EAAC1, in the retina of representative vertebrate species. Neurosci Lett 211:191-194.

Schwartz EA, Tachibana M (1990) Electrophysiology of glutamate and sodium co-transport in a glial cell of the salamander retina. J Physiol (Lond) 426:43-80.

Shigeri Y, Shimamoto K, Yasuda-Kamatani Y, Seal RP, Yumoto N, Kakajima T, Amara SG (2001) Effects of threo- $\beta$-hydroxyaspartate derivatives on 
excitatory amino acid transporters (EAAT4 and EAAT5). J Neurochem 79:297-302.

Shimamoto K, Lebrun B, Yasuda-Kamatani Y, Sakaitani M, Shigeri Y, Yumoto N, Nakajima T (1998) DL-threo-beta-Benzyloxyaspartate, a potent blocker of excitatory amino acid transporters. Mol Pharmacol 53:195-201.

Sun JY, Wu LG (2001) Fast kinetics of exocytosis revealed by simultaneous measurements of presynaptic capacitance and postsynaptic currents at a central synapse. Neuron 30:171-182.

Tachibana M, Kaneko A (1988) L-Glutamate-induced depolarization in solitary photoreceptors: a process that may contribute to the interaction between photoreceptors in situ. Proc Natl Acad Sci USA 85:5315-5319.

Tachibana M, Okada T (1991) Release of endogenous excitatory amino acids from ON-type bipolar cells isolated from the goldfish retina. J Neurosci 11:2199-2208.

Takahashi M, Kovalchuk Y, Attwell D (1995) Pre- and postsynaptic determinants of EPSC waveform at cerebellar climbing fiber and parallel fiber to Purkinje cell synapses. J Neurosci 15:5693-5702.

Taschenberger H, von Gersdorff H (2001) Mechanism of EPSC reduction after glutamate uptake blockade at the calyx of Held synapse. Soc Neurosci Abstr 27:607.18.

Taschenberger H, Leão RM, Rowland KC, Spirou GA, von Gersdorff $\mathrm{H}$ (2002) Optimizing synaptic architecture and efficiency for highfrequency transmission. Neuron 36:1127-1143.

Tong G, Jahr CE (1994) Block of glutamate transporters potentiates postsynaptic excitation. Neuron 13:1195-1203.

Traynelis SF, Silver RA, Cull-Candy SG (1993) Estimated conductance of glutamate receptor channels activated during EPSCs at the cerebellar mossy fiber-granule cell synapse. Neuron 11:279-289.
Tzingounis AV, Lin CL, Rothstein JD, Kavanaugh MP (1998) Arachidonic acid activates a proton current in the rat glutamate transporter EAAT4. J Biol Chem 273:17315-17317.

Vandenbranden CAV, Verweij J, Kamermans M, Müller LJ, Ruijter JM, Vrensen GFJM, Spekreijse H (1996) Clearance of neurotransmitter from the cone synaptic cleft in goldfish retina. Vis Res 36:3859-3874.

Vandenbranden CAV, Yazulla S, Studholme KM, Kamphuis W, Kamermans M (2000) Immunocytochemical localization of the glutamate transporter GLT-1 in the goldfish (Carassius auratus) retina. J Comp Neurol 423:440-451.

von Gersdorff H, Matthews G (1994) Dynamics of synaptic vesicle fusion and membrane retrieval in synaptic terminals. Nature 367:735-739.

von Gersdorff H, Vardi E, Matthews G, Sterling P (1996) Evidence that vesicles on the synaptic ribbon of retinal bipolar neurons can be rapidly released. Neuron 16:1221-1227.

von Gersdorff H, Sakaba T, Berglund K, Tachibana M (1998) Submillisecond kinetics of glutamate release from a sensory synapse. Neuron 21:1177-1188.

Wadiche JI, Kavanaugh MP (1998) Macroscopic and microscopic properties of a cloned glutamate transporter/chloride channel. J Neurosci 18:7650-7661.

Wadiche JI, Amara SG, Kavanaugh MP (1995) Ion fluxes associated with excitatory amino acid transport. Neuron 15:721-728.

Watzke N, Rauen T, Bamberg E, Grewer C (2000) On the mechanism of proton transport by the neuronal excitatory amino acid carrier 1 . J Gen Physiol 116:609-621.

Zerangue N, Kavanaugh MP (1996) Flux coupling in a neuronal glutamate transporter. Nature 383:634-637. 